\title{
A newly found edition of "forty positions" by Abu Said Abu al-Khair
}

\section{Seyed Mohammad Bagher Kamaladdini}

\author{
Department of Persian Literature and Language, Yazd Payam Noor University \\ E-mail address: kamaladdini@pnu.ac.ir
}

Keywords: Abu Said Abu al-Khair; positions; forty positions

\begin{abstract}
Abu Said Abu al-Khair (357_440H.) is one of the greatest mystics of Islam whose published works, the "Secrets of monotheism in positions of Sheikh Abu Said Abu al-Khair" and "expressions and words of Abu Said Abu al-Khair" are considered as the most important mystical sources. Secrets of monothsiem is a valuable book that gives us clear information about mystical character of Abu Said Abu al-Khair. Many scholars have been able to extract clear and informative points from this book for their research, have about Abu Said Abu al-Khair's way of life. ALso "expressions and words of Abu Said Abu al-Khair" is an important book that contributed to the greater understanding of emotions and moods of Abu Said Abu al-Khair.

But what has long been common among experts is that Abu Said Abu al-Khair has had another work called "positions" that has existed and is gone. Although some Persian language and literature researchers including Professor Shafi'i Kadkani have carefully examined and presented many copies of this work some of which have been published, but still there is a lot more to "positions".

In this paper which has been written in a descriptive and analytical method with research approach firts we study works that have introduced this book and then a rare manuscript of this valuable work will be introduced. This version starts with praising of God and then discusses forty mystical positions like nothingness, remorse, repentance, devotion, battle, etc.
\end{abstract}

\section{BACKGROUND}

Abu Said Abu al-Khair is one of the greatest Persian speaking mystics whose remaining works are of utmost importance for researchers and those interested in mysticism. So far, the efforts of researchers have given birth to two of Abu Said Abu al-Khair's works: "Secrets of monotheism in positions of Sheikh Abu Said Abu al-Khair" and "expressions and words of Abu Said Abu alKhair". What has been published on Abu Sais has been effected by these two works like Abu Said's Rubaiyat. But the researches done by great Persian language and literature experts have also revealed another valuable work named "Abu Said's positions" or "forty positions", also added to the works of this renowned Sufi. Until recently this work was thought to have been destroyed, but the efforts of different experts and especially Professor Shafi'i Kadkani it was published and is now available to the public. In this paper we present another version of "Positions" also old and rare that can provide useful information for researchers and those interested in works of this Sheikh, buried in Meyhana.

\section{A brief look at the rise of Maqama writing:}

In the late fourth century, a branch of storytelling so famous and propsperous at that time in Arabic prose, was a technique initiated by Badi'ozaman Hamadani and called as "positions" imitated later on by other prose writers in Arabic and Persian. They all called it for the same name. (Khatibi, 1996, vol. 1: 543)

Professor Maleko Sohara Bahar writes about this: "In the fourth century due to the promotion of literature, the multitude of books, book congestion and the stand of the authors and scribes in courts of rulers, caliphs and Molouk, there was a great rivalry among them and theological competition and teleological contestations reached their paroxysm. Besides assuming good meaning, good words and good hand writing every author attempted to use poets' words and inspirations in tehir work. This meaning accompanied the evolution and change, caused over time by the weakness of 
old habits and customs, that together started a revolution in the art of prose writing where new techniques of writing became visible like Muvazana, Muzdavaj, Gharineh Sazi etc. This all led to writing Maqamahs with its effects becoming evident a hundred years laterin in Dari Farsi and thus a technical prose arose in Farsi through an imitation of Arabic literature. (Bahar, 1991: 240)

\section{Writing Maqamh meaning and concept:}

To describe the lexical meaning of Maqamah Doctor Shoghi Zyf writes "In the poetry before Islam, Maqamah has two senses: A) a tribal assembly and association and B) the congregation or community present. But in the Islamic era, it has been used to signify: the chamber where someone stands against the caliph and others and speaks the sermon. Badi'ozaman Hamadani has used it to signify storytelling and making speeches in the House, whether the person be sitting or standing. " (Shoghi Zyf, Bi Ta: 7)

Doctor Ali Abumlham defines Maqamah lexically also to mean a House and a group of people and the message or the sermon delivered to them in the community. (Abumlham, 2002: 7)

But technically Maqamah is a kind of story without literal or spiritual fine details which are very important. It has no story value and authors write them to be able to use fine and prestigious expressions and words much as they like and present their art in synthetic verbs and rhetorical rhymes. In this field Ibn Tiqtiqa says: "There is no adnvantage in Maqamahs beside practicing the art of composition, awareness of poetry and prose schools and some judgment and experience." (Khatibi, 1996: 547)

On the supremacy of verbal and rhetorical aspects over fiction writing in Maqamah, doctor Anzabi Nezhad says: "It can be said that three out of four or even more of effort and creativity in writing Maqamah goes to the verbal texture and this is why they say in Maqama story is poor, to the extent that the reader is not interested in hearing the story, but in finding verbal fineness and rhetorical language." (Hamidi, 1993, Introduction: 7)

Also Professor Hamilton says: "All the art of writing Maqamah in the work is in its talented and creative art. Some modern critics have expressed the opinion that Maqamah in Semitic literature comprises the climactic stage in presenting literary issues. In the midst of this stream, there is the ongoing literary context mobilization common among the Aryans and Semites the most fundamental of which are epic, drama and novel. " (Hamilton, 1973: 47)

\section{A look at the life of Abu Said Abu al-Khair:}

Abu Sa'id Abul Khair (357-440 H), an Ash'ari Sufi and mystic was born in Mayhana a village in Northern Khorasan. He learned Quran in his hometown under Abu Muhammed Anazy and Arabic literature under Abu Saeed Anazy. Then he went to Merv to study within five years the science of the scattered and the allied (comparative jurisprudence among the four schools) under Abu Abdullah Khezri. After Khezri's death, he went to Abu Bakr Qaffal and learnt law from him for five years. At this time many of the great scholars of the era like Abu Ali Senji and Nasser Marvzi and Abu Muhammad Juwaini were his classmates. After $378 \mathrm{H}$ he went to Sarakhs to complete his education under Abu Ali Zaher ibn Ahmad al-Faqih. After his death, through Luqman Sarakhsi he found a way to the monastery of Abu Alfazl Hassan Sarakhsi and as influenced by speeches of his master, he put away the official and apparent science and through him; he found a way to Abu Abdul Rahman Salami. After his death he went to Amol in Tabarestan and resided for a year in Abu Al-Abbas Qassab Amoli's monastery and received the clothes of consecration from his hands. Abu Saeed was an expert in sciences of interpretation, Hadith, Fiqh and Sufism and miracles are attributed to him. Ie learned hadiths from Abu Ali Shaboubi and Abu Bakr Jowzeqi. Many scholars of hadith and Sufism traditions had received their permissions to recite hadiths from Abu Sa'id. Hassan Samarkandi went to his association and Abu Bakr Abdullah Nassaj, Abu Ali Farmedi, Abu Omar and Beshkhani were all Abu Saeed's disciples. Several poems are attributed to Abu Said in a series called "Abu Said's quatrains" but what is certain is that only two quatrains and two verses are truly of him. Abu Sa'id's love of poetry and his mentioning good poetry in different appropriate states and writing thoese two quatrains have made people attribute romantic and mystical poetry to 
him as they also did to Omar Khayyam. Abu Saeed finally died in Mayhana and was buried right there. His life and miracles are described in his two books by his descendants: "Secrets of monotheism in positions of Sheikh Abu Said Abu al-Khair" and "expressions and words of Abu Said Abu al-Khair" . (Nassiri, 2005: 166)

About this mystic, Attar also writes "Abu Said Fazlullah ibn Abu al-Khair Ahmad ibn Muhammad ibn Ibrahim, one is of the few exceptional figures in the history of Iranian mysticism born in $375 \mathrm{H}$ in Mayhana close to Mirv. After many trips he stayed in Nishapur, and because of his extensive knowledge, penetrating personality, grace and unprecedented kindness, in the late fourth and early fifth century $\mathrm{H}$ his name has been known and loved by sages eveywhere in the Islamic world to Andalusia. Years after his death, two of his grandchildren gathered his remarks, manners and traditions in two books, both of fine and interesting Persian Sufi literary works "Secrets of monotheism in positions of Sheikh Abu Said Abu al-Khair" written by Muhammad bin Munawar and "expressions and words of Abu Said Abu al-Khair written by Jamaluddin Abu Ruh Abdullah." (Attar, 2007: 869)

\section{Notes on the version introduced by Professor Shafi'i Kadkani:}

Professor Shafie Kadkani has always had a great effort in rewriting manuscript and editing works of great Iranian mystics and has also introduced a newfound copy of Abu Said's positions. One of the reasons that prompted him to do such a search was to note that Attar quoted stories of Abu which were not in "Secrets of monotheism in positions of Sheikh Abu Said Abu al-Khair" or "expressions and words of Abu Said Abu al-Khair". He writes: "During the years I made researches about Attar's Hagiography and his poetry in the books Manteq Utteir, Mosibatnameh, Asrarnameh and Elahinameh which are about to be published I've always regretted why some anecdotes Attar recite about Abu Said Abu al-Khair are not in "Secrets of monotheism in positions of Sheikh Abu Said Abu al-Khair" and "expressions and words of Abu Said Abu al-Khair". (Shafii Kadkani, 1380: 68)

Afterwards he describes merits of his newfound version of Positions as such:

"1. Anecdotes of his life that define some aspects of his biography.

2. Anecdotes of his own words that clarify his classes even more

3. Poetry which is examined for the first time in the history of Persian literature.

4. Another version about the revelation story of some of his poetry in his other Maqamas.

5. Some of his brilliant and surprising Shatths never seen recorded anywhere else

6. Some references to the historical geography of his life events.

7. Some terms rarely seen in our dictionaries.

8. Some words quoted from Shaikh seen nowhere else (no) and which are always nice and deep and of utmost importance.

9. There is a beautiful and bright Persian translation of some o Shaikh's Arabic phrases, that can not be seen in "Secrets of monotheism in positions of Sheikh Abu Said Abu al-Khair" and "expressions and words of Abu Said Abu al-Khair".

10. Differences in details and even in stories "plot"s. "(Ibid: 69)

\section{A look at Dr. Iraj Afshar's report on Dushanbah 555 collection:}

After valuable information he gives about Dushanbah 555 collection, Dr. Iraj Afshar refers to Abu Said's positions. About the Dushanbah 555 collection he writes "There is a collection numbered as 555 at the Library of the Academy of Sciences of Tajikistan in Dushanbah that gained some reputation in the world of Persian literature because of some Hafiz sonnets written on the side of some of its paper. Late Myrzaof published those sonnets in a small book in 1972 named as fortythree sonnets. " (Afshar, 1417 AH, 1966)

About Abu Said's positions they have written in the margin of the content: "treatise of Positions quoted by Abu Said Abu al-Khair in forty positions. Since a part of the version was missing it was written in the same (form) on a separate page and annexed to the paper. the book has been written "Finished the position with divine aid and peace be upon the prophet" 14 b, 21 a. (ibid: 1366) 


\section{A look at Abu Said Abu al-Khair's positions:}

Forty position or Arbain is a mystical work that describes levels of mystic spiritual journey in forty steps. "Sheikh Abu Abu al-Khair said a Sufi must take forty steps so that his walk in the alley of knowing god is correct. The first step is "good will". A mystic must be so in good will that if they show him the world and its grace and the hereafter and its paradise and the trouble and its tabulation, he must pass the world and its grace to the pagan and the hereafter and its paradise to the faithful and he must choose trouble and tribulation for himself. The next step is remorse. If They are alone, they must see God, a change in the whole world must not move their inside and the divine turbulation must not repel their affection. The third step is "repent ". All the people repent of what is unlawful and avoid prohibited matters to avoid suffering. They repent of the lawful they eat so that they might not fall in the unlawful and the doubtful. The fourth step is "devotion". All the world would like to have comfort and with it richnessand money, but they want suffering and with it property and closeness. the fifth step is "trying". People struggle to make twenty of their ten but they try to disappear their twenty. The sixth step is "meditation". Meditation is holding their self in privacy so that the King of the universe keeps them innocent from sin. The seventh step is "patience". If they see disasters of the both world they will fetch no sighs and if the whole world loves them, they will but wait patiently. The eighth step is "remembering". They think of him in their hearts and sing his name on their tongue. Wherever they despair they will only go to him. The ninth position is "satisfaction". If He gives them no clothes, they will be happy and if He keeps them hungry they will be happy and they will never choose anything for themselves. The tenth position is "opposition with the self". For seventy years their self moans because it wants something but will only encounter suffering. The eleventh step is "approval". Evil and health and bless and vice would be the same for them. The twelfth position is "surrender". If the shaft of catastrophe hits them from the ambush of vice they will throw themselves in catapult of surrender and open their hearts and souls to those shafts and make a shield of their life and psyche against arrows of destiny. The thirtieth position is "trust". They don't ask people for anything, nor do they ask Him. However, they worship him because of him and there will be no question or speech. Inevitably the King of the universe will make them attain their wish more than they can even count. The fortieth position is that of "piety". Of all the world, they have but a simple clothes in hundred pieces from burlap and carpet and torn felt. Those clothes are a thousand times more loved by them than are Saqlatoon and Miqrazi. The fifteenth position is "worship". They are busy all day and all night to recite the rosary and are standing to say prayers. They serve their people with might, their hearts of full love of love of god and their heads occupied by a view of the King. The sixteenth position is "abstention". They will not eat all meals and will not wear all garments and will not sit with all people with anyone and will only think and talk of god. The seventeenth position is "Sincerity". All night, all day they are fasting and say prayer, and if their self in does not stand in obedience and sees obedience, they will grant their fifty years prayers to a dog or to someone and say said: O soul! Do you see what you did does not merit God? The eighteenth position of "truth". They will take no step but in the right way and take no breath but of righteousness. Their tongue talks their heart, their heart talks their head and their inside gives all but news of God. The nineteenth position is "fear". With a look at his justice they melt in fear and have no hope in their worshipping. The twentieth position is "Hope". With a look at his grace, they ride with joy and have no fear or groaning. The twenty-first position is "mortality". They must put their self in the furnace of mortality so that they will be empty of whatever but him. Their tongue must not talk of the world and must only chant his name is not on his tongue. Their body must only move in obedience. Their heads must only shake of his thinking. The twenty-second position is "immortality". Once they look at right they must see him and once they look at the left they must again see but him. They must see him in all states. They must survive with his immortality, satisfied buy his ourselves please, and be happy with his grace and gifts. The twenty third position is "certain knowledge" and if they look closely they will see from low to high with no veils in between. The twenty fourth position is "righteous knowledge". Now if they look closely they will pass all the made and the natural and will see right into Him with no veils in between. The twenty-fifth position is "knowledge of god". They will only know god from both 
worlds and in their knowledge there will be no perturbation involved. The twenty-sixth position is "effort". They will worship Him with their heart and soul and feel no doubt in their worshipping Him. The twenty-seventh position is "kindness". Their will is greater than the two worlds and the whole heavens and their blessings cannot satisfy them at all. The twenty-eighth position is that of "love". From the whole existence they love but one and their friendship is one because in evident and concealed they are always the same. Their bodies melt in desire and their hearts run for Him. They think neither of their children nor of their wives, neither of the world not of its enrichments. The twenty-ninth position "ecstasy". No one can find them in the world, in the cemetery, in resurrection, on the hereafter bridge but they prefer to be where He is, where they are God is as well with them. The thirtieth position is "closeness". If they say O God forgive the whole heresy and rebellion and idolatry because of our work, the King of the universe does not reject their prayer. The thirty-first position is contemplation. They will only think of him and will find peace in remembering his name. The thirty-second position is "joining". There will be no veil between their hearts and Him ... and nothing will block their way. The thirty third position is "discovery". There is no veil between God and their hearts ... and nothing can block the way which is in between. The thirty-forth position is "service". They will not be away from service for a single glimpse and will never be absent from seeing Him. The thirty-fifth position is "abstraction". If they take them to hell, they say hurray and if sent to paradise, they say hurray. Neither heaven nor hell, males them afraid or happy. They do not abstain from love and the will always be away from the whole world. The thirty-seventh position is 'loneliness". They are alone among the world's people. If they hit them they will not lose their way and if they treat them well they will not be deceived. The thirty-seventh position is "expansion". If the King of the universe at the time of death sends them the angel of death they will not obey its commands unless when He tells them to die. They don't fear question of the death angels. They only think of stepping into the heaven and do not fear the day of judgment and will not look into the faces of virgins until they see god himself. The thirty-eighth position is "realization". They are amazed and faer people and hang nto the door of god's house. The thirtyninth position is of "finality". These people there will have arrived, suffered lands of perturbation and seen god with the eyes of their hearts. The fortieth position is "mysticism". A mystic is who is way from all desires and his inside has no infliction. He will never speak of ignorance, senseless words and backbiting. They see nothing in the world and will only look at god. Of all these forty positions, each is of one of the prophets that start with Adam (pbuh) and end with Muhammad (pbuh)

(Damadi, 1996: 58_61)

\section{A handwritten version of Abu Said's forty positions contained in the margins of the 555 manuscript:}

One of the rare manuscripts of Abu Said's forty positions is a copy held in Tajikistan. Positions are written at the margin of the manuscript and contains forty positions. In this version the order of the positions differ from the earlier version just mentioned. For example, in this version "nothingness" is mentioned first, whereas in previous versions "good will" is mentioned first. Also in this version there is a description which is different from previous introduced versions.

In this version, mystical steps of spiritual journey are mentioned as: 1 nothingness, 2 remorse, 3 repentance, 4 devotion, 5 battle, 6 meditation, 7 patience , 6 remembrance, 9 self opposition, 10 happiness, 11 confirmation, 12 submission, 13 trust, 14 piety, 15 worship, 16 abstention, 17 sincerity, 18 righteousness, 19 fear, 20 hope, 21 mortality, 22 survival, 23 certain knowledge, 24 evidence of self, 25 gnosis, 26 kindness, 27 love, 28 poverty, 29 change, 30 closeness, thirty one friendliness, thirty two join, 33 revelation, 34 risking, 35 abstraction, 36 destiny, 37 expansion, 38 surprise, 39 destination and 40 mysticism and Dervish-ness. (adapted from a rare version of Positions manuscript)

Appendix: First page of Abu Said's forty positions manuscript contained in the margin of the manuscript 555: 


\section{References}

[1] Abu al-Khair, Abu Said, "a rare edition of Abu Said's positions » from Dushanbah 555 collection, Tajikistan Manuscripts Institute

[2] Abumlham, Ali, 2002, Maqamate e Badi'ozaman Alhamzany, Beirut: Al-Hilal Darolmaktabah

[3] Afshar, Mahmoud, "Dushanbah 555 collection" Almuhaqaq Altabatbai fi Zikrah Alsanaviyah Aloula, V 3, Qom: Moassasat Alol-Bayt Lahya' Altorath

[4] Bahar, Mohammad Taghi, 1991, Stylistics, V 2, Tehran, Amir Kabir, 6th ed

[5] Hariri, Abu, 1985, Maqamat e Hariri, a research of Ali Rawaqi, based on Darsadr Beirut publication, Tehran: Shahid Mohammad Rqwaqi Institute

[6] Khatibi, H., 1996, prose art in Persian literature, V 1, Tehran: Zowwar

[7] Damadi, Seyyed Mohammad, 1996, a commentary on Abu Said's positions, Tehran: Tehran University Press

[8] Shafii Kadkani, Mohammad Reza, "the ancient and newly found Maqamas of Abu Said Abu alKheir", Nameye Bahaestan, year 2, 2nd ed, Fall-Winter 2001, pp. 65_78

[9] Zeyf, Shoghi, Bi Ta, Almaqamah, Cairo: Dar Olmaarif, 7t Ed

[10] Attar, Mohammed Bin Ibrahim, 2007, Hagiographie, Istilami Mohammad, Tehran: Zowwar

[11] Nassiri, Mohammad Reza, 2005, Asarafarinan, Tehran: cultural figures community

[12]Hamilton, Alexander, 1983, Introduction to Arabic literature, tr Azand, Yaghoub , Tehran: Amirkabir 